\title{
Advancing Archaeological Research through Remote Sensing: The Example of Tylliria Area in Cyprus
}

\author{
Vasiliki Lysandrou ${ }^{1,2 *}$ and Athos Agapiou ${ }^{1}$ \\ ${ }^{1}$ Department of Civil Engineering and Geomatics, Cyprus University of Technology, Cyprus \\ ${ }^{2}$ Department of History and Archaeology, University of Cyprus, Cyprus
}

Submission: February 06, 2017; Published: February 28, 2017

*Corresponding author: Vasiliki Lysandrou, Remote Sensing and Geo-Environment Research Laboratory, Department of Civil Engineering and Geomatics, Faculty of Engineering and Technology, Cyprus University of Technology, 2-6, Saripolou str., 3603, Limassol, Cyprus,

Email: vasiliki.lysandrou@cut.ac.cy/athos.agapiou@cut.ac.cy

\section{Short Communication}

Tylliria area is situated in the north-west part of Cyprus. Its geographical territory counts several villages of Nicosia and Paphos Districts, on the basis of the modern administrative division of the island. The area is bounded in the eastern part from Kampos River and the village of Pomos in the west (Figure 1).

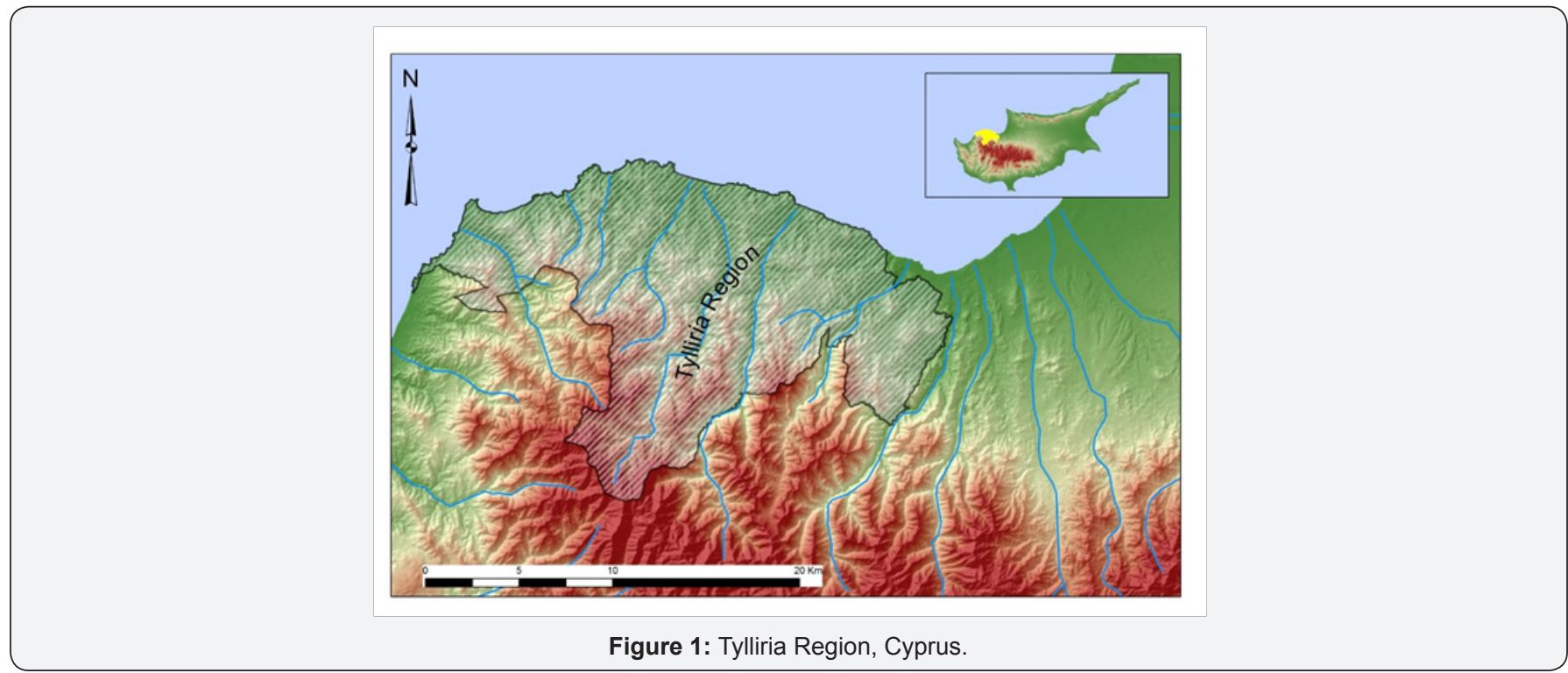

In antiquity, the area was surrounded by two powerful citykingdoms, that of ancient Soloi to the east and Marion to the west. The territorial extend of these two kingdoms has not yet been defined and therefore the role and position of their intermediate area known as Tylliria is still to be revealed. In any case, it should be considered that the area would not have stayed unaffected by these kingdoms, forming part of the wider socio-economic and administrative environment prevalent on the island during the Iron Age and later during the Archaic and Classical period or even after the abolishment of the city-kingdoms during the Hellenistic period.Furthermore, evidence from late historical eras until the late Medieval and Byzantine period is also attested in the area $[1-4,14]$.
As understood, Tylliria area holds undoubtedly an important position in the study of history and archeology of Cyprus, boasting rich archaeological evidences still to be detected and revealed. However, this comes in contrast to the archaeological activity performed over the years in the area, which, is very limited compared to other parts of the island. Tylliria area is considered, from an archaeological point of view, one of the least studied areas on the island. The reasons for that can be briefly attributed to the modern political history of Cyprus that rendered the area not easily approached and thus isolated and distant from the main modern cities. Another obstacle in performing archaeological research is the rough geomorphology of the area that makes investigation difficult, still further time and money consuming. 
One of the most recent archaeological investigations in the area was carried out in 2009 by Kykkos Museum (under the auspices of the Department of Antiquities of Cyprus). The preliminary results of the in situ archaeological survey indicated archaeological evidence in the area.The investigation concerned a documentation survey in order to identify, amongst other, the potential extension of a known ancient necropolis, possibly dated to the Hellenistic period and reused during the Roman one, the tombs intensity/consistency and spatial distribution, their geomorphological setting and their state of preservation $[5,6]$. During the survey, more tombs -part of other ancient cemeteries- have been identified in the region belonging to different chronological periods of the history of Cyprus. The identified tombs were all hewn out of the natural rock, mainly cut into the steep and rough rock face (Figure 2). The in situ observations and documentation have been completed with the topographical mapping of the tombs. The study area was firstly observed mainly through cadastral maps. All data collected were elaborated for digitization and mapping and introduced into a Geographical Information Systems (hereafter GIS) environment. In total five main areas have been identified with rock-cut ancient tombs, all of them looted. In the first two areas more than 70 individual tombs have been accurately recorded.

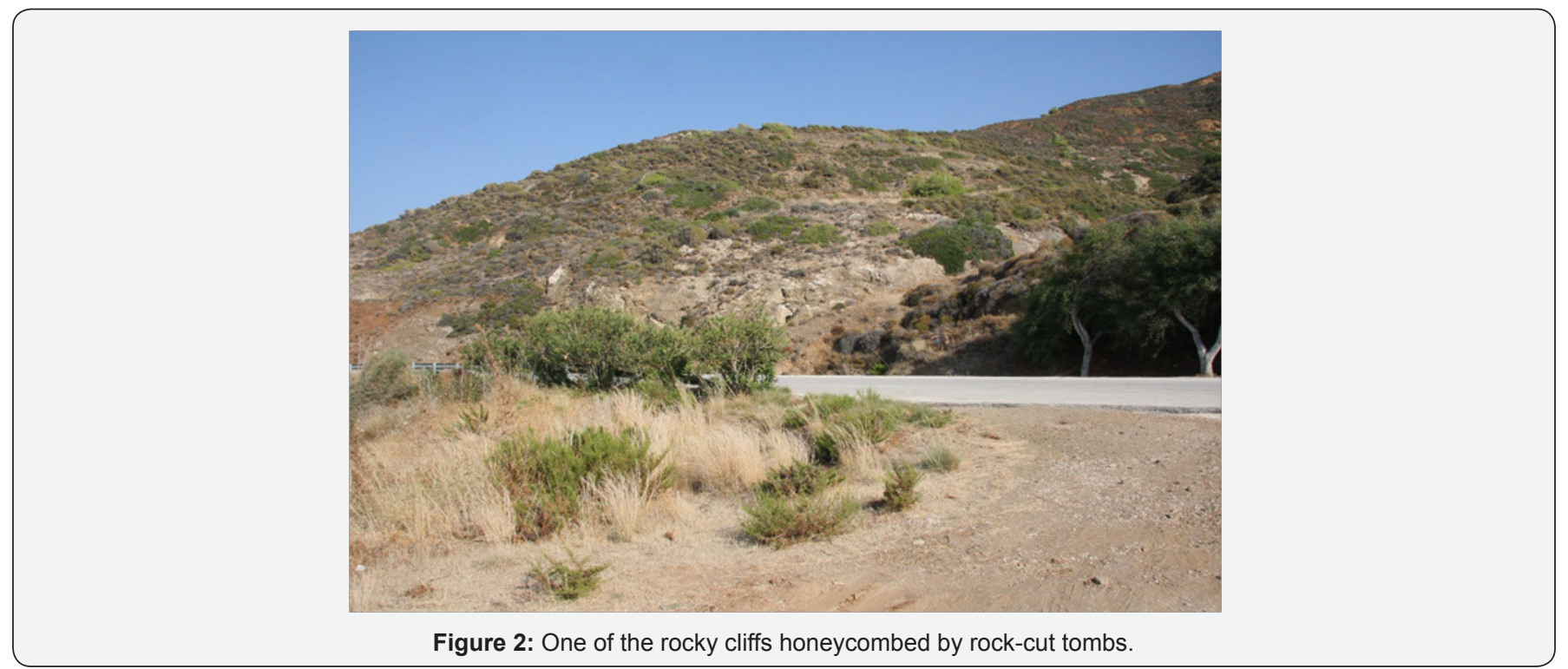

In parallel, archival indexing from the Department of Antiquities of Cyprus was carried out, in order to identify areas spotted in the past, mainly through foot surveys and try to reconstruct the up to date know archaeological testimonies of the area through the GIS. Even though information retrieved from these archives was limited and very concise, it still remains valuable since it's the only information regarding the official investigations in the area (in their great majority unpublished). A number of problems needed to be solved during this phase with the most important one to be related to the exact site location, communicated in the archival reports with the toponym of the area rather than using coordinate system.

Unfortunately, such gaps in the archives, makes the today archaeological investigations even more difficult and problematic. In addition, the hilly and difficultly accessible terrain of the area can also delay or even postpone traditional archaeological surveys in a landscape level. Even though the characteristics of Tylliria area are not unique within archaeological research, still are here presented as an indicative example of the difficulties that currently archaeologists seek to solve. The problems are even growing taking into consideration the general decrease of budgets allocated for such archaeological investigations and the systematic land use and land cover change of the "archaeolandscapes" due to modern development.
Is becoming evident that new ways and new tools of performing archaeological investigations in a landscape level are in demand and need to be adopted and exploited by archaeologists in order to facilitate their research both in terms of field work as well as for desk-base data analysis and visualization. Within this concept Remote Sensing (hereafter RS) technologies can play an important role.

Certainly, RS offers new perspectives in archaeological research [7]. Optical Remote Sensing can detect phenomena on the surface associated with subsurface relics, while the use of infrared and thermal electromagnetic radiation can be used in order to detect underground archaeological remains. For example, spectral anomalies in the very near infrared part observed over crops may be linked to the presence of buried archaeological features. Radar sensors, having the ability of large-area coverage, cloud penetration and all-weather acquisition can compensate some weaknesses of optical images.

RS as a non-destructive technique can contribute to the distant investigation of an archaeological site prior, during and post excavation. Such techniques can monitor the surroundings of an archaeological heritage site by recording any modifications due to climate changes and other natural and/or anthropogenic threats and pressures. Satellite remote sensing has become a 
common tool of investigation and prediction of environmental change and scenarios through the development of GIS-based models to support decision-making. By blending together satellite remote sensing techniques with GIS, the monitoring process of archaeological sites can be efficiently supported in a reliable, repetitive, non-invasive, cost-effective and time efficient way.

New technologies (such as radar satellite images, interferometry and other) have already been applied at various archaeological sites [8-10]. New satellite sensors, such as Sentinel missions, are also expected to support archaeological research in the near future. The WordView-3 sensor with a spatial resolution of $31 \mathrm{~cm}$ highlights the latest achievements of space technology. Using data with such an improved quality, scientists can seek even more elaborate details for sub-surface remains and a better understanding of archaeolandscapes [1113].

Tylliria area urgently needs a detail digitalizationin a landscape level, since otherwise vital information will be lost over the years. This urge is becoming even more emerging in light to the several local and governmental efforts of retrieving the area from its isolated position, by boosting amongst other the modern development of the region.

Due to the difficulties mentioned earlier, an extended and different approach of this landscape is demanded. The use of satellite archive and high resolution multispectral datasets together with the exploitation of aerial images of the area can help archaeologists to understand better the landscape of the area or even prioritize the areas to be investigated. Such data can also reveal hidden and still unknown archaeological sites. Definitely, the current documentation of the tombs and several other sites, clearly indicates only a small part of the still undiscovered archaeological vestiges of the area. This is pointed out even more distinctly by the extensive necropolis discovered in Tylliria region, considering that the identified cities of the dead (necropolis) have once been established to serve the corresponding cities of the living, still to be discovered.

\section{Acknowledgment}

The authors would like to thank Kykkos Museum that back in 2009 funded the project and the Department of Antiquities of Cyprus that supported this initiative. The present communication is under the "ATHENA" project H2020-TWINN2015 of European Commission. This project has received funding from the European
Union's Horizon 2020 research and innovation programme under grant agreement No 691936.

\section{References}

1. Lysandrou V (2010) A Medieval watch tower at Kato Pyrgos Tillirias. Proceedings of the A' Conference Tylliria, Memories, History and Archaeology, Nicosia, pp. 211-230.

2. Perdikes S (2010) Archaeological excavation at locality Avli, Pano Pyrgos Tyllirias. Proceedings of the A' Conference Tylliria, Memories, History and Archaeology, Nicosia, pp. 163-210.

3. Myriantheus D (2010) Churches and chapels in Tylliria. Proceedings of the A' Conference Tylliria, Memories, History and Archaeology, Nicosia, pp. 121-162.

4. Philotheou G (2010) Panayia Galoktisti church at Kato Pyrgos Tyllirias. Proceedings of the A' Conference Tylliria, Memories, History and Archaeology, Nicosia, pp. 97-120.

5. Lysandrou V, Agapiou A (2010) Comparison of documentation techniques for the restoration and rehabilitation of cultural heritage monuments: the example of Pyrgos 'Troulli' medieval tower in Cyprus. Proceedings of the $3^{\text {rd }}$ International Euro-Mediterranean Conference on Digital Heritage (EuroMed2010), (8-13 November 2010, Limassol, Cyprus), Archaeolingua, Budapest, p. 21-26.

6. ViolarisY (2010) The excavation of a tomb of the Hellenistic and Roman period in Mansoura. Proceedings of the A' Conference Tylliria, Memories, History and Archaeology, Nicosia, p. 37-64.

7. Agapiou A, Lysandrou V (2015) Remote sensing archaeology: Tracking and mapping evolution in European scientific literature from 1999 to 2015. Journal of Archaeological Science: Reports 4:192-200.

8. Chen F, Masini N, Yang R, Milillo P, Feng D, et al. (2015) A space view of radar archaeological marks: First applications of COSMO-SkyMed X-band data. Remote Sens 7(1): 24-50.

9. Stewart C, Lasaponara R, Schiavon G (2014) Multi-frequency, polarimetric SAR analysis for archaeological prospection. International Journal of Applied Earth Observation and Geoinformation 28: 211-219.

10. Tapete D, Cigna F (2012) Rapid Mapping and Deformation Analysis over Cultural Heritage and Rural Sites Based on Persistent Scatterer Interferometry. International Journal of Geophysics 2012: 618609.

11. Agapiou A (2016) Orthogonal equations for the detection of archaeological traces de-mystified. Journal of Archaeological Science: Reports. Doi: 10.1016/j.jasrep.2016.07.004.

12. Giardino JM (2011) A history of NASA remote sensing contributions to archaeology. Journal of Archaeological Science 38(9): 2003-2009.

13. Lysandrou V, Agapiou A (2010) Documentation of ancient tombs in Tilliria area (Cyprus) using Geographic Information Systems. Proceedings of the $38^{\text {th }}$ International Annual Conference on Computer Applications and Quantitative Methods in Archaeology (CAA), (6-9 April 2010, Granada, Spain.

14. Chotzakoglou C (2010) Fumbling about the region of Tillyria in the byzantine and postbyzantine period, Cyprus. Proceedings of the A' Conference Tylliria, Memories, History and Archaeology, Nicosia, pp. 299-324. 


\section{Your next submission with Juniper Publishers} will reach you the below assets

- Quality Editorial service

- Swift Peer Review

- Reprints availability

- E-prints Service

- Manuscript Podcast for convenient understanding

- Global attainment for your research

- Manuscript accessibility in different formats

( Pdf, E-pub, Full Text, Audio)

- Unceasing customer service

Track the below URL for one-step submission https://juniperpublishers.com/online-submission.php 